\title{
Idealistic Education in the National Socialist Era in Germany: Character and Race Unity
}

\author{
Murad Karasoy ${ }^{1}$ \\ ${ }^{1}$ Ataturk Faculty of Education, Marmara University, Istanbul, Turkey. \\ Correspondence: Murad Karasoy, Ataturk Faculty of Education, Marmara University, Istanbul, Turkey. E-mail: \\ karasoymurad@gmail.com
}

Received: June 7, 2018

Accepted: July 2, $2018 \quad$ Online Published: July 20, 2018

doi:10.5539/jel.v7n5p136

URL: https://doi.org/10.5539/jel.v7n5p136

\begin{abstract}
It is understood that the education's being brought under the control of government and educational activities carried out under the name of character and race unity education were tools for the destruction of the individual and masses during the national socialist era in Germany. For this reason, the state's monopolizing and more or less intervening in moral education can be regarded as a fascist act. The connection of altruism with race and the fact that race consciousness has aspects supporting the idealism have been abused by the fascist education. The fact that the individuals were directed to race by being impregnated with the sense of altruism showed how the two basic principles of national socialist education complemented each other. On the one hand, the individual was taught how to be altruistic, on the other hand, the superiority, holiness and supremacy of race were romanticized, and the infrastructure of the reason for the necessity of being altruistic was instilled on their mind.

This study, which was made by reviewing the documents of Hitler (1938), Kubizek (1954), Schirach (1967), Gay (1968), Fest (1970 and 1973), Noakes (1971), Giles (1985), Domarus (1990), Burleigh and Wippermann (1991) and Canetti (2014), not only shows the fact that the character and race unity education that Nazis gave in schools wasn't compatible with universal principles, but also the fact that the number of children in school age who died during the World War II reached a half million teaches how to act against the negative success of the fascist education that is focused on destruction.
\end{abstract}

Keywords: character, Hitler, idealistic education, National Socialism, race unity

\section{Introduction}

The reason why the Germans are respected among other nations is that they have strong character (Hitler, 1938). The character education was being neglected for a long time in German schools caused both morale loss in community before World War I and the country was losing its reputation among other nations. For this reason, all fields of art that drive the youth into immorality, and moral education were put under the order of the National socialist state, and severe measures were taken in this regard, including restrictions on individual rights and freedoms (Karasoy, 2018).

The Nazis, who were claiming that not every nation could be a master race, believed that a race must have the following characteristics in order to be a master race: idealism, socialism, pure blood, physical and ideological perfection (Hitler, 1938; Schirach, 1967). Since sacrifice is a concept to be earned at a young age, Nazi education is designed as an idealistic education that will give this virtue from top to toe.

Establishing a great civilization is directly proportional to the ability to establish a great community that emerges with the tendency of an individual to put his/her personal interests aside. Since master races dedicate their self to the life of the society, they will easily be able to sacrifice themselves when circumstances require to do so. The source of the ability to build civilization in master races is not the intellectual abilities of individuals. On the contrary, it is the individual's self-sacrificing his/her personal idea, thought and interest for the sake of community. This sacrifice will ultimately benefit the individual. The self-sacrifice of one's own life to protect the life of community has been regarded as the highest point of the altruism (Hitler, 1938, p. 496). This sense of self-sacrifice as an essential aim of the Nazi education, is one of the central objectives of the National Socialist politics for the operability and continuity of the state. When we look at the picture of national socialist politics (Foreign Affairs, Interior, Economy, Education, Defense, etc.) in a holistic way, it is understood that the essence 
Nazis expected from the education is to raise a generation that will even self-sacrifice themselves to fulfill the given order without thinking or questioning (Nyssen, 1979; Mazower, 2013; Noakes, 2006).

Hitler described this sacrifice as idealism. According to him, the fall of idealism will weaken the force that is the first condition of civilization and creating the society, and with the reign of selfishness over the nation, the bonds of this order, which holds society together, will begin to unravel (Hitler, 1938, p. 330).

Since the idealism as the individual's devotion of all his/her existence to the existence of society is the first condition of all organized affairs, it is also the ideal that nature wants. This view, which is fully compatible with the Nazis' understanding of nature and naturalness, is one of the intellectual foundations underlying all educational institutions and Nazi educational policies. According to this idea and also in line with Nazism's monist and organizational mentality, the state ensured the necessary precautions to be taken for the educational organizations, from kindergarten to university, in order not to allow the emergence of any different German type (Tent, 1982; Sherratt, 2014).

According to the national socialist ideology, the state is a means rather than an end. One of the conditions for a race to establish a great civilization lies in the ability of that race to be a state because the ability to create a civilization is a characteristic only possessed by master races. The state's goal is to provide the development of people who are physically and morally integrated and the continuity of this development. For this reason, the task of the National Socialist State is not to create but to lead to the forces within it (Hitler, 1938, p. 428).

Among the Nazis, there was an idealism along with a sincere hatred towards the system before coming to power. This mis-founded idealism, has promised people that a national community to be built and a new society to be established. According to this ideal, powerless people will not be exploited by the big capital and will not live by the threat of the organized working class. Discriminatory feelings will dissolve in this idealism (Kershaw, 2007, p. 336). This growing idealism of the Nazis was nourished by the admiration of the masses who lived in the hope of "what if it happens" and by the unlimited flattery shown by almost whole society.

\section{The Foundations of Idealistic Education Before the National Socialism}

The efforts for Germany's unity, which Bismarck set forth in 1871 by supporting it with the constitution, unfortunately deepened class, regional and religious differences. The masses ostracized things that were different than themselves and somehow separated them from the other parts of community. Bismarck's culture camp project, which he conducted in Germany in the same years, against Catholic education, institutions and the clergy, backfired and caused the spread of Catholicism in Germany. On the other hand, the Socialist Law he enacted against Socialism also led to the empowerment of socialists. This picture, formed in Germany prior to the First World War, provided a suitable basis for German Nationalism to radicate (Kershaw, 2007, p.94-97).

It is presumed that what prepared Germany's collapse before World War I was that fact that spread of distrust and cowardice, which are considered to be the cause of the disappearance of the energy that is supposed to exist in everything that is German, over the public as a disease through German educational institutions. The fact that education gave only the information but little thought the concepts of population and power, that the character education was considered unimportant and was not sufficiently involved in curricula, that the joy given by the sense of responsibility was not established, and the strengthening of the willpower and the development of the decision-making ability were neglected summarize the pre-World War I situation of German education. In fact, it is accepted that this situation continued till the National Socialists' accession to power (Karasoy, 2018, p.210).

As it has been said, Hitler belived that Germans are respected by other nations because of their strong character. The negligence of nourishing a strong character in German education caused both morale loss in community and also reputation loss among other nations (Hitler, 1938).

After the First World War, the adoption of the view, which was held by German elites, that the only way for the German nation to revive was to be economically strong was strongly rejected by the Nazis. These views which were raised by the famous German economist and politician Hugo Stinnes (d.1924) created a staggering surprise. However, the National Socialists believed that the revival could be possible by the means of education. Therefore, the national revival of France which was believed due to the reform movements in the educational policies became a model for National Socialists (Kandel, 1924). Accordingly, the curricula of all educational institutions must be re-established on the humanist basis.

The government, which was in power in Germany before the First World War, was not able to prevent the spread of syphilis and tuberculosis diseases and could not prevent the people from becoming dirty in political, moral, and customary sense, which was a vital factor for the German nation. The increase in prostitution, which caused the spread of syphilis in the country, was conveyed to the people as a social poisoning by the Nazis. According to 
them, the way to prevent prostitution are not moral conferences or education. They believed that prostitution, which is dangerous enough to destroy the German nation, can be prevented only through early marriage. Young people should be married as soon as possible with various means to be provided by the state. (Hitler, 1938; Schirach, 1967). Hitler had no respect for the womankind. He claimed that, men could spend their life neatly without any need for women. This was entirely up to the will of men. His closest friend, Kubizek, said that, Hitler had not been in a relationship with any women in Linz and Vienna (Kubizek, 1954, pp. 115-116).

In 1925, Germany became a part of the international community by being a member of League of Nations. This process, which also meant the disappearance of causes that gave rise to the Nazi success before 1923, mean that Germany would be the US follower even if it is a bit late. Those years were a cradle to the climb of the Weimar culture to the peak of New Objectivity and an extraordinary cultural development. For example; Bauhaus's modern architectural experiences, the expressionist paintings of Paul Klee and Wassily Kandinsky, the paintings of Otto Dix and social criticism in George Grosz's cartoons, the brave musical works of Arnold Schonberg and Paul Hindemith are important in the sense that they show the way that New Germany followed (Fest, 1973, p. 92; Gay, 1968, pp. 99-100). The rituals such as the proliferation of cinemas and dance halls in the streets, the increase of mass entertainment forms, the spread of jazz music among the youth, and the decline of crime rates are important in that they show the direction of German society. According to the Nazis, this situation meant leaving yourself to some kind of comfort. Therefore, the reactions to "street culture", which Goebbels, who was responsible for the Nazi Party's propaganda affairs, exhibited as a reaction to the efforts of Americanization of the popular culture in 1920's metropolitans, spread to large areas towards the end of the 1920s (Kershaw, 2007, pp. 326-327).

The fact that sufficient importance was not attached to the intellectual and physical development, and the students were loaded only with information were other points that the Nazis criticized in German Education prior to World War I. According to Hitler, the strong and energetic thinking power could only be found in a strong and healthy body (Hitler, 1938, p. 444). Unity and solidarity of the nation could be possible with intellectual and physical development. Forgetting this principle led to corruption in German society during and after the war. According to him, caring only about the intellectual development in education encouraged cowardice and sexual perversion, and killing the ability of a man to predominate, while caring only about the physical development led to the poisoning of spirit and spirituality.

The Nazis claimed that the education before the war had made the students mature and get old early. The reason for this was that teenagers in school age fell into the trap of prostitution in 13-14 years of age. The theater, cinema, literature, the other branches of fine arts, media and propaganda materials, which dragged the youth into prostitution were put under the control of National Socialist moral state. In this respect, individual rights and freedoms can be neglected for the sake of saving and protecting the race and if necessary the most severe and precise measures should be taken (Hitler, 1938, p. 279).

The German Nationalist Protection and Defiance Federation (Deutschvolkischer schutz und trutz-bund), which was founded in early 1919 with the initiative of the Pan-German Union, became an important bridge for the Nazi Party to create its first supporters. Teachers with Pan-German views and a great many students, whose national prides were hurt and who had to change their career plans, became members of this federation (Noakes, 1971, p. 11). Hitler also invited German youth to be alert to foreign teachers (Hitler, 1938, p. 10). The most basic feature of the teachers that the students should be careful about was their being in the rhetoric and/or action to alienate the youth from the German glory and honor. Thus, even the smallest retrospective or prospective criticism is unacceptable. This new situation not only forced all teachers to praise the Germans and German history but also did not allow them to tell any negative things about the past and the future and to think analytically and critically. Hitler's assigning the control of this process to the auto-control of German youth, formed the basis of the human power and management form of the gestapo regime that he was going to build.

The fact that the Nazis began to implement their education policies as soon as they came to power in 1933 brings to mind the presence of a serious intellectual preparation prior to this process. Heidegger's determination in 1929 can be considered as the center of such preparation, which was concerning German intellectual life and that "If it is not made dominant by supporting it with native teachers and educators, it will be abandoned to the Jewish influence as that would be not possible to be saved from its impact" shows that the subject was discussed back in those years by German intellectuals, was addressed as a problem and that solutions were produced. The fact that the training of new domestic educators and their appearance in the workplace were considered as the solution for diminishing the Jewish influence indicates that the war continued with education. Asking the educators only to be "native" gives a terrifying clue regarding our understanding of how National Socialism was in the view of marginalization. Asking them to be new, on the other hand, shows a revolutionary approach indicating that the 
clocks were set to zero in relation to their own past.

The National Socialist German Students' League was founded in 1926 under the leadership of Wilhelm Tempel who was a student at faculty of law. Then, in 1929 Baldur von Schirach became the leader of the organization. Schirach, who had shown a very successful leadership performance, had been saying that the National Socialist German Students' League had three main tasks: 1. To ensure that National Socialist thoughts were reached the large masses, 2. To spread the Nazi ideology in German universities and to raise leaders for NSDAP. 3. To keep all students under control (Schirach, 1967; Giles, 1985; Pine, 2010, p. 33). Schirach had fulfilled the practical part of Hitler's idealistic education. Schirach, who had felt in love with Hitler, had had a huge influence in spreading the national socialist thoughts in educational organizations.

In late 1932, there were four waves where students left the school. The lucky ones could find jobs but they were also fired from work within a few months. Number of suicides and crime rate among the youth increased. Among the university students, there were many students who supported and joined the Nazi party. The proportion of Nazis in the University was higher than other organizations. Indeed, the students who were members of the National Socialist German Workers' Party (NSDAP) and the German Communist Party (KAP) were basically reacting to the Weimar Republic (Democracy). They rebelled against the system which turned them adrift in many respects. The militant parties playing upon the utopian expectations filled the void created by this alienation as well (Fest, 1970; Kater, 1985, pp. 217-243). The national socialist movement was the leading and the most important one among these.

\section{Idealistic Education in the Period of National Socialism}

It is understood that the fascist movements emerged when these circumstances arouse. This illness of which place and time were not known, nesting in young hearts, had the opportunity to spread through artisans, peasants and farmers whom we can call petit bourgeois. Nazism, which made good use of the youth base, aimed to maintain the continuity and dynamism of its ideology through this mass. Since the places, where the young population were present, were educational institutions, schools at every stage became the origin of the work for Nazism. When we think that fascism is an ideology based on racial hatred, it is better understood what scientific data and criteria the educators and those who were being educated, whose essence and way was love, were raised with in such environment of hate, and what kind of society was tried to be created.

National socialist politics put nourishing nationalism as the most important function of education. In this framework, what is to be done in a short term is a good planning. It is certain that its outcomes will only be seen over a long period of time. For this reason, since ten years or twenty years would not be enough, it is necessary to risk the centuries. A common national feeling would only be built through school and propaganda because the whole nation's thinking the same way on the same issue required a long perception study (Hitler, 1938, pp. 77-78).

In a well-prepared speech over two hours, describing the outline of the government program, Hitler made in Reichstag on March 23, 1933, after drawing the portrayal of the evil of the circumstances when he took the power, he promised a comprehensive moral renewal with the help of education, mass media and art (Domarus, 1990, pp. 232-235). According to this, all educational activities to be carried out should take children towards the goals of the national socialist state ideology step by step, and make them capable of building up the resoluteness to be needed in the future (Hitler, 1938, p. 453) The national socialist state transformed into an educator state with all its functions. This transformation means the use of cultural, intellectual and moral power by the state.

\section{Master Races and Idealistic Education}

One of the important characteristics of national socialist education is its strong avoidance of individualistic approaches. According to this, people's pushing their personal interest aside is proportional to their establishment of large and powerful communities, for sacrifice that one will make for the benefit of his/her fellows is a feature of master races. Master races consciously sacrifice their individuality and privacy to the benefit of the society. In fact, sacrificing one's own life to protect the life of the community is the highest level of sacrifice. For this reason, it can be said that their civilization and prosperity is not depend on the intellectual power of their individuals. Therefore, education should also be designed not to be individualistic but to give such social consequences. Hitler called this as idealistic education. Idealistic education is the self-sacrifice of an individual for the sake of the society and the ones of the same kind. Nevertheless, this is not an emotional situation. In addition to the fact that idealistic education is the first condition for civilization, only such education can create the concept of "human being". Idealistic education has transformed human to one of the smallest parts of the order in the nature. As idealism of human begins to disappear, we see that force, which is the first condition of civilization, loses its importance. According to Hitler, a person who only pursues personal interests in fact falls to 
the Hell from the Heaven (Hitler, 1938, pp. 327-328). Just because of this reason, educational programs and educational administration should be applied at every stage of education for the continuation of the German nation and race, because mankind's salvation also depends on master German race's proving itself. The meaning of Schiller's words "you can never protect unless you devote your life" means that the survival of a race requires personal sacrifices.

In fact, the main element of fascist teaching is individualism as seen in the concepts such as 'the leadership principle' and 'family politics'. The socialist-collectivist aspect of fascism was borrowed from the socialist tendencies of the mass on which it based, while its individualistic aspect reflects the large capital and the interests of totalitarian rulers (Reich, 2002, p. 82). When it comes to relations with big business owners, it is rather meaningful that fascist individualism establishes an area where the totalitarian rulers can act comfortably and arbitrarily (Tröger, 2011, p. 297). Of course, it is not difficult to guess that this relationship, which is based on self-interest, is mutual. When the issue is addressed in terms of national socialist education philosophy and policies, it is not possible not to notice a very distinct paradox. We can say that an understanding which obliterates the individualism from educational policies and is the most important feature of national socialist education, but imposes an intellectual and social foresight, not accepting monist and individualist ideas such as 'the leadership principle' and 'family politics', and dualism can cause a lot of social and global crisis in short or long term. Fascism, while hoping for help on social issues from the spirit of the mass on which it based, is quickly becoming an individualist in the two most important decision-making mechanisms of society, the management and the family. We can say that both its providing a flow of ideological information in a top down manner and keeping control over the political elite within the framework of this ideology, by connecting all education organizations, especially universities, to the principle of leader (führerprinzip), are in harmony with other social, political, cultural and economic policies that it implements.

\section{The Role of History Teaching in Race Education}

Hitler said that an important issue to focus on education was that education should provide the racist state with the opportunity to develop national pride. For this reason, history education should start with a general history of civilization. According to him, education should be performed in an organized manner, and as a result of the education, a young should be raised as a real German. A sincere synthesis of nationalism and a sense of social justice should be instilled into the hearts of young people through education. The racist state must ensure the lasting of German race through educating the youth. No German should graduate from school without precisely understanding the blood purity and its necessity for the continuation of the German race (Hitler, 1938, p.473). National socialist education can provide output only to that state. It should not be possible for any other ideology rather than this to exist and wait for a return from the National Socialist State. The German national pride must be given to the generations, or even be developed through education and its instruments. This critical task, dictated to education, has posed many preparations and activities. It is understood that this caused a great endeavor from the preparation of the textbooks in accordance with this policy to the intellectuals of the period's justifying the foundations and rightfulness of this philosophy. The so-called German national pride has always been there as it can be seen when the history of civilization is examined. This is about to be forgotten due to the wrong politics and approaches of the German governments in the past periods. The national pride of a race, especially if it is German race, is considered to be an important sign of its survival. Thus, the national pride of the German race which has always existed should be brought into open by re-teaching the History lesson starting with the History of Civilization, and it should be ensured that the German youth graduate by knowing and having this spirit (Hitler, 1938; Blackburn, 1985; Giles, 1985).

While giving a special importance to the teaching of the History Course, Hitler also criticized the fact that this course was not taught in a way that it deserves in schools. According to him, history lesson was about teaching students the reasons that caused the historical events and making them investigate the things which made them necessary. In this lesson, it is necessary not to forget what the essential is, without discussing the details too much. The reason why Hitler loved his history teacher is that he opened up the possibility of being a revolutionary for him at a young age by instilling these feelings. Moreover, his beginning to understand that the general history affected everyday matters reached him the motto of "I do not need to make an effort to learn history, history will teach itself to me" (Hitler, 1938, p. 12). Even if his beginning to take lessons from History and even the History's presenting itself to him seems mysterious and fascinating to the people, this is nothing but a megalomaniac mood. In the national socialist education, history should teach students that not what happened in the past but the way to follow for the life of its nation to survive.

The Nazis were insistent on working as Germans, not just people. The adjustments in the Nazi History lesson were set to highlight the students' sense of being German. The content of these texts were formed with the effect 
of two characters: haste and acting quickly as well as anxiety and sacrifice mixed with the fear of death to the extent to be called obsession. Some of the authors accelerated the writing process of the textbooks that composed of purely dramatic events, involved passionate emotions and irrationality, and thus, they removed the obstacles in front of the student and his impartiality. The reader was overwhelmed by an irresistible current. The Nazis achieved privileges with unprecedented historical resources for the early German period. According to their claim, the superior German race developed as a distinct type within the racial incubator originating from natural coincidence. These members who were especially skillful and were supposed to be very careful to preserve the purity of German blood (Blackburn, 1985, s. 34-39; Giles, 1985).

The educational value in interpreting the history was adjusted with reference to the idealistic education, the formal attitudes lying in its ability would then determine both the actions of the students and their true opinion. The nature of the history lesson raised the most suitable teachers, but the purpose of historical studies was not the development of thought, scientific criticism, or aesthetic appearance. All historical efforts were a preparation for students to engage in mass action (Childs, 1938; Feiten, 1981; Giles, 1985; Füssl, 1995).

Hitler convinced people of imperial European ideal, just like himself. Thus, the Nazis thought that it was their duty to establish an empire that would elevate Germany to the world domination. For this reason, the Nazis saw their own imperial aspirations in connection with that of other vanguards. Just as the British manage Asia or Africa, the Nazis would well manage Europe (Arendt, 2011; Mazower, 2013, p. 42-45). Of course, they believed that they could accomplish this by starting with education. History-based idealistic education was structured in line with this goal.

\section{National Socialist State and Character Education}

According to Nazism, the State is a community organization composed of creations that are not physically and morally similar. The state has been established to provide a more qualified life to the generations of the people who make it up and to make people reach the target God has shown. It is understood that the task of all Germans' physically and morally resembling each other has been loaded into two things: Nature and Education (Hitler, 1938). It is thought that the natural laws' being valid in social life by social physics will result in physical similarity, while a mono-type education will result in moral similarity. It can be said that this is the thinking underlying the preservation of the physical similarity by forbidding the marriages with foreigners (non-German) because of the moral and value-oriented nature of Nazi education rather than scientific reasons. Since the state is a racial organ, and the approach that the state can't be economical institution was adopted, education was also shaped in line with this presupposition. The protection and preservation of moral virtues in society through education will also create the ideal economy. For this reason, the main objective of education, just as that of everything, is to ensure the protection and survival of the race. All inputs and outputs in education were organized according to this understanding.

According to the Treaty of Versailles signed at the end of the First World War, the removal of military training considered as a period in which the deficiencies of German education were compensated, is another subject criticized by National Socialists (Canetti, 2014, p. 212). For this reason, it was emphasized that the establishment of alumni monitoring system was necessary, besides monitoring the physical development of the students, the efforts to prepare infrastructure for students to continue their developments after they graduate should be made. Monitoring the development processes of the youth by government were considered among the most essential rights and duties of the national socialist state.

The national socialist state, aiming to outline the general cultural programs in the primary and secondary education stages, wanted to make the student specialize in a certain field in the future. In the remaining time from the eased teaching programs, the character education of students allowed to strengthen their willpower and develop their decision-making ability.

The national socialist state regarded being tight-lipped and neither being chattering nor denouncing others as a virtue. Schools are the institutions that are obliged to bring these virtues to the students. German pedagogues must certainly teach the students to be tight-lipped and be invulnerable against suffering. Teachers should never allow students in class to complain about and to inform against each other. National socialist education should develop willpower, decision-making ability and sense of responsibility in students. Fear of giving wrong answer was considered to be a bigger fault than the false in the answer. The clothes of students and young people should be arranged as a supporting element for the education, and should serve in accordance with the National Socialist Movement, is another issue that was addressed.

It is believed that the regulation of education programs in schools as only information uploading, not mentioning morals and love of country and nation will cause the child to grow insensitive to spiritual information in the 
future. Thus, it is inevitable that he/she will revolt against the state and the authority. In order to be able to transform a race into a nation, first of all a flawless and strong social environment must be established. The social environment is a must for disciplining the individual. Such environment can only be created first in school, then in the family.

According to the national socialist state, the belief that power and ability are not something that can be earned through education is quite meaningful in the sense that it shows what will not be expected from education (Hitler, 1938; Schirach, 1967). The child who grew up with this dogma would have learned from the that: "I cannot get strength and ability by receiving education. So whatever the role the government thinks is appropriate for me, I must play that role." In National Socialism, in which these two concepts are supposed to come from birth, the structure of the mechanism that will decide whether or not these rituals exist in a person has always remained unknown. It is not difficult to predict that the remaining meanings of these concepts as relative strengthens the National socialism's hand and leads to arbitrary practices.

The national socialist ideology took the opportunity to put its educational considerations into practice for the first time in Thuringen (at the north of Bayern) state elections, held in December 1929. It passed ten percent threshold by receiving $11.3 \%$ of votes for the first time, and had the opportunity to become a partner in the state government to be established. As Hitler responded positively to the proposal to be involved in the government, the ministries that the Nazis would get were wondered. Hitler asked the two ministries, whom he considered as the most important ones, as the condition for involving in the government: Education and Internal Affairs. He wanted to control the culture to be given at schools and universities and the education policies in those institutions with the Ministry of Education, while he wanted to control the police and government employees with the Ministry of Internal Affairs. With the two ministries being given to NSDAP, Hitler has given the same name to both ministries: Wilhelm Frick. Hitler gave Frick the mission of purging Marxist and democrat employees, teachers and police officers and bringing the education to national socialist line. And Frick appointed race theory specialist Dr. Hans Günther as the department chair for a department to be opened with the name of Racial Issues and Racial Knowledge (Rassenfragen und Rassenkunde) to start with (Kershaw, 2007, pp. 338-339). There were instructors, teachers and students among the people that formed the Nazi Party at the beginning of the 1930's. In some states, NSDAP was almost like a civil servant party.

The annexation of Austria was carried out in March 1938. Hitler, who entered Vienna in company with the cheering of One State, One Nation, One Leader (ein Reich, ein Volk, ein Führer), was welcomed by an enthusiastic crowd. By the order of the Archbishop of Vienna, all churches were adorned with swastika flags. All Catholic Churches rang a bell for Hitler. The workplaces were closed, the workers in the factories were laid on the streets for duty and the schools were temporarily closed days before. The students who were members of the Hitler Youth and German League of Girls (BDM), and other civilians welcomed Hitler by being transported to Vienna by buses from various parts of Germany and attended the public meeting held (Burleigh \& Wippermann, 1991).

The Third Reich schools have aimed at training and teaching intelligent German pupils. Humboldt's educational vision, which emphasized individuality and intellectualism in the period of national socialism, was condemned because it was perceived as one of the reasons that weakened the national (völkisch) community spirit (Hahn, 1998, pp. 83-84).

The national socialist state advocated free education for talented poor children. This approach strengthened Nazism's hand in the petit bourgeoisie and in the countryside. The children stayed with their families until their first years. Later on, they were asked to join the Nazi organizations 'jungvolk' and 'Hitler jugend' to be developed as a good Nazi and a good soldier. The state should have a single youth. Art and agriculture will be taught, course hours will be shortened and the history will be transformed into a form describing the nation, the number of universities will be decreased, everyone will work with digging tools, the large industry will be nationalized, and land will be distributed to the veterans (Gerede, 1994, p. 305)

\section{Discussion}

In Germany, during the period of National Socialism, a policy of education focused on destructing and being annihilated was determined. This education, which had symmetrical features with the other politics of the Nazi state, was called idealistic education by Hitler, character and race unity are what meant by that phrase. During this period, the practical and theoretical applications of the Nazi ideologists that supporting this meaning were witnessed. (bu cümle anlaşılmıyor) The Nazis, either in their newly established schools or in the classical schools remained from II. Weimar period shaped the education regarding the issues of the curriculum, the organizational structure, the planning, the management and the control of the education according to character 
and race education. Furthermore, they did not even settle with it and they spread the idealistic education with the non-formal education instruments together with the formal education institutions.

National socialists' belief that societies can build civilizations only through power led them to develop strategies to gain strength and not to lose the strength. Civilization established by the power obtained by idealistic education will continue to protect itself again with the help of character and race education. In national socialist German society consisting of physically and morally similar individuals, racial education was intensively pursued so that individualism did not dominate society. And with this, it was aimed that the society could be easily managed and mobilized as well as the Nazi state would not lose its power.

The Nazis used the fact that the Weimar Republic, established after the World War I, neglected the character and race education and did not include them in the curricula as a political material. Character and Race Unity was tried to be established through social and artistic developments and the perception of external enemy which was built spreading the perception of Americanization of the popular culture/street culture hegemony throughout the society.

It is understood that the Nazis also meant the physical and intellectual development with the concept of character and race unity. Moreover, they meant the protection of the race and the pure German blood by the race and the intellectual unity and not to think differently by the character unity. Shaping the art with all its faculties in the framework of Nazi moral state politics led to cultural, social and individual problems to an extent that cannot be slurred over by the justification of the state reflex of protecting the youth.

National socialists did not leave the character and race education to educators who did not have German blood. This theory, which was spoken before the Nazi government, was put into practice towards teachers in the form of banishment after 1933. The systematic banishment period towards the teachers and the students in pre-school, primary education, secondary education and higher education took its place in the wall of shame of the educational history.

National socialism never aimed at "educating everybody" but giving "proper" education to people to meet its needs. The fact that the number of students who enrolled in universities in this period is lower than that of the Second Reich period is remarkable, for it shows the outcome of this policy (Pauwels, 1984, pp. 147-148).

Manipulating the feelings of German youth in a lyric manner, and thus, the efforts of transforming them into a soldier of Nazism are among the most secret plans of this period. The effort to eliminate the possibility of the teacher's hindering the activities of Nazism through education by positioning the student in a position to supervise the teacher is very important as it shows the relation of Nazism with education. We can say that the Nazis, who claimed to make an effort essentially for the prosperity and superiority of German race, cared neither the teacher nor the students. There is only one purpose for Nazism and it is to build the German leviathan. Every way was considered legitimate and holy for the sake of achieving this purpose.

According to national socialist education, all ideas, all teachings and all sciences should provide the development of the German race and the independence of the homeland, and support this duty given to the German race by the creator of the universe. And the nationalist state must ensure that the race remains pure. It should take the necessary precautions in this regard. Physically strong parents should be allowed to raise children. The state has the right to intervene the sick individuals who want to have children. The individual should not do anything other than obey to the state in this regard.

National socialist education includes reductionist and dogmatic elements. It has been acknowledged that a selfish one will always be selfish and will remain selfish forever, and an idealist will always remain idealist. Since the character was assumed to form very earlier, it was believed that educating those with bad characters would be of no use.

The national socialist education system wanted to highlight selected names from German history and make them the common property of the entire German nation as an idol and as an ideal. Thus, it is aimed to create enthusiasm and excitement with the common knowledge to be established, which would provide unity and solidarity among the students. Heroes, the source of pride for the German people, were introduced to the new generation in schools.

We can list the educational reforms that national socialists wanted to do as follows: free education provided by government, establishment of educational organization structure, simplification of school system, providing the children in disadvantaged regions with equal opportunities in education, increasing the teachers' level of education. When we look at whether these objectives were achieved at the end of the National Socialist Period, we can say that the outcome is a frustration. But the historical documents reveal that it achieved the purpose of 
building a youth focused on destructing and being annihilated.

\section{References}

Arendt, H. (2011). Totalitarizmin kaynakları - 2 (3rd ed.). İstanbul: İletişim Yayınları.

Blackburn, G. W. (1985). Education in the third reich. Albany: New York/NY, USA: State University of New York Press.

Burleigh, M., \& Wippermann, W. (1991). The Racial State: Germany 1933-1945. UK: Cambridge University Press.

Canetti, E. (2014). Masse und macht. Frankfurt: Fischer Taschenbuch.

Domarus, M. (1990). Hitler, speeches and proclamations 1932-1945 the chronicle of a dictatorship (M. Fran Golbert, Trans., Vol. 1). Bolchazy-Carducci Publishers.

Fest, J. C. (1970). The Face of the third reich (M. Bullock, Trans.). New York: Pantheon Books.

Fest, J. C. (1973). Hitler der aufstieg. Frankfurt-Berlin-Wien: Verlag Ullstein.

Gay, P. (1968). Weimar culture: the outsider as insider. New York: Harper \& Row.

Gerede, H. (1994). Sığınakta kaleme alınan belgesel, harb içinde Almanya. İstanbul: ABC Ajansı yayınları.

Giles, G. (1985). Students and national socialism in Germany. Princeton. https://doi.org/10.1515/9781400857784

Hahn, H. J. (1998). Education and society in Germany. Oxford.

Hitler, A. (1938). Mein Kampf. 389. Auflage, München: Zentral der NSDAP.

Kandel, I. L. (1924). The Reform of secondary education in France. New York: Teachers College, Columbia University.

Karasoy, M. (2018). Almanya'da nasyonal sosyalizm döneminde eğitime genel bir bakış. Journal of Human Sciences, 15(1), 209-224. https://doi.org/10.14687/jhs.v15i1.4600

Kater, M. H. (1985). Generationskonflikt als Entwicklungsfaktorin der NS-Bewegung vor 1933, in Geschichte und Gesellschaft. Deutschland: Vandenhoeck \& Ruprecht.

Kershaw, I. (2007). Hitler birinci cilt hubris 1889-1936 (Z. Biliz, Trans.). İstanbul: İthaki.

Kubizek, A. (1954). The young Hitler, The story of our friendship (E. V. Anderson, Trans.). London: Allan Wingate.

Mazower, M. (2013). Hitler imparatorluğu işgal Avrupa sında Nazi yönetimi. İstanbul: Alfa Tarih.

Noakes, J. (1971). The Nazi party in lower saxony, 1921-1933. Oxford University Press.

Noakes, J. (2006). Nazism 1919-1945: a documentary reader vol.4 the german home front in World War II. United Kingdom: Exeterpress.

Nyssen, E. (1979). Schule im Nationalsozialismus. Berlin: Heidelberg.

Pauwels, J. R. (1984). Women, Nazis and universities, female university students in the Third Reich, 1933-1945. Westport-Connecticut, London-England: Greenwood Press.

Pine, L. (2010). Education in Nazi Germany. Berg: New York: Oxford.

Reich, W. (2002). Faşizmin kitle ruhu anlayışı (B. Onaran, Trans., 3rd ed.). İstanbul: Payel Yayınları.

Schirach, B. (1967). Ich glaubte an Hitler. Hamburg: Mosaik Verlag.

Sherratt, Y. (2014). Hitler 'in filozofları (Ö. Eldaş, Trans.). İstanbul: Say Yayınları.

Tent, J. F. (1982). Mission on the rhine. reeducation and denazification in American-occupied Germany. Chicago: University of Chicago Press.

Tröger, A. (2011). Kadın montaj hattı proletaryası yaratılması. In R. Bridenthal, A. Grossmann, \& M. Kaplan (Eds.), Biyoloji kader olunca Weimar ve Nazi Almanyası'nda kadınlar (ss. 289-327). İstanbul: Kalkedon Yayınları. 


\section{Copyrights}

Copyright for this article is retained by the author, with first publication rights granted to the journal.

This is an open-access article distributed under the terms and conditions of the Creative Commons Attribution license (http://creativecommons.org/licenses/by/4.0/). 